\title{
SHADING EFFECT ON COFFEE TREE IN FORMATION STAGE
}

\author{
Kleso Silva Franco Junior ${ }^{1}$, Ligiane Aparecida Florentino²
}

(Received: March 01, 2019; accepted: April 30, 2019)

\begin{abstract}
According to the Intergovernmental Panel on Climate Change, global warming is expected with temperature rise and changes in the rainfall in tropical regions, including soil warming, which may lead losses to perennial plants. This phenomenon causes researchers to search through science alternatives in order to minimize these impacts. The objective in this research was to evaluate the cultivation of different plants in a intercropping for the coffee tree shading and its influence on the seedlings establishment, development, coffee growth and the maintenance of lower soil temperatures. The experiment was

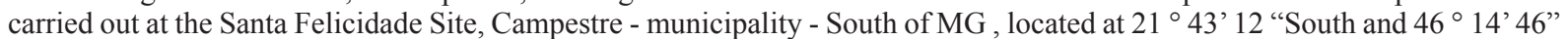
West at an altitude of 1.106 meters. The cultivar used was the Catuai IAC 144, was intercropped with the following species: maize (Zea mays L.), guandu (Cajanus cajan L.), crotalaria (Crotalaria spectabilis L.), mucuna (Stizolobium aterrimun) and control without any intercrop, totaling five treatments. The plants sowing for shading was performed using a manual planter and the planting was done in 4 plots per treatment, totaling 20 experimental units in a randomized block design with 14 coffee plants per plot. The 10 central plants were analyzed. At the end of the experiment, the following characteristics were evaluated: seedlings establishment, growth in height, average length of plagiotropic branches, number of internodes in plagiotropic branches, coffee canopy and soil temperature. The data were statistically interpreted by means of variance analysis. The means were grouped by the Scott Knott test at $5 \%$ probability using the statistical software SISVAR ${ }^{\circ}$. According to the results obtained the shading plants in intercropped with the coffee tree managed in the post-planting and first-year phases contributed to a better coffee tree development, observed mainly in the treatments using the Crotalaria and Guandu species.
\end{abstract}

Index Terms: Coffea arabica, intercropping, global warming.

\section{EFEITO DO SOMBREAMENTO EM CAFEEIRO EM FORMAÇÃO}

RESUMO: Segundo o painel Intergovernamental de Mudanças Climáticas há previsão de aquecimento global com elevação da temperatura e mudanças no regime de chuvas nas regiões tropicais inclusive com aquecimento do solo que poderá acarretar prejuízos às plantas perenes. Este fenômeno faz com que pesquisadores busquem através da ciência alternativas a fim de minimizar estes impactos. Esta pesquisa teve como objetivo avaliar o cultivo de diferentes plantas em consórcio para o sombreamento do cafeeiro e sua influência no "pegamento" das mudas, desenvolvimento, crescimento do cafeeiro e na manutenção de menores temperaturas do solo. O experimento foi conduzido no Sítio Santa Felicidade, município de Campestre - Sul de MG, localizado às coordenadas geográficas $21^{\circ} 431^{\prime} 12^{\prime}$ 'Sul e 46 14 ' 46" Oeste, a uma altitude de 1.106 metros. A cultivar utilizada foi o Catuai IAC 144 consorciada com as seguintes espécies: milho (Zea mays L.), guandu (Cajanus cajan L.), crotalária (Crotalaria spectabilis L.), mucuna (Stizolobium aterrimun) e o controle sem nenhum cultivo intercalar, totalizando cinco tratamentos. A semeadura das plantas para o sombreamento foi realizada utilizando uma plantadeira manual e o plantio foi efetuado em 4 repetições por tratamento, totalizando 20 unidades experimentais em delineamento de blocos casualizados com 14 plantas de café por parcela sendo analisadas as 10 centrais. Ao final do experimento foram avaliadas as seguintes características: "pegamento" das mudas, crescimento em altura, comprimento médio dos ramos plagiotrópicos, número de internódios nos ramos plagiotrópicos, área da copa do cafeeiro e a temperatura do solo. Os dados foram interpretados estatisticamente por meio de análise de variância, e o agrupamento de médias realizadas pelo teste de Scott Knott a 5\% de probabilidade, por meio do software estatístico SISVAR ${ }^{\circledR}$. De acordo com os resultados obtidos a utilização de plantas de sombreamento em consórcio com o cafeeiro, manejadas na fase de pós-plantio e primeiro ano, contribuíram para um melhor desenvolvimento do cafeeiro, observados principalmente nos tratamentos com a utilização das espécies Crotalária e o Guandu.

Termos para indexação: Coffea arabica, consórcio, aquecimento global.

\section{INTRODUCTION}

According to the Intergovernmental Panel on Climate Change (IPCC) (2013), in several reports released about global warming forecast have been highlighting the rise in temperature on the planet and serious changes in the rainfall regime, especially in the tropical regions (PENEREIRO and MESCHIATTI, 2018). According to Miranda (2016) for coffee cultivation, the effects of these climatic changes besides promoting a reduction of crop areas can also lead to large production losses in the harvests of this product. Data from the United Nations Organization - ONU on climate change state that: combining high temperatures and water deficit, the consequence will be a considerable reduction in grain cultivation in the main producing states in Brazil, such as Minas Gerais and São Paulo. Therefore, maintaining soil water availability is a major challenge considering

${ }^{1}$ Centro Superior de Ensino e Pesquisa de Machado/CESEP - Av. Dr. Athaide Pereira de Souza s/n 37.750 - 000 - Machado- MGkleso.junior@yahoo.com.br

2Universidade José do Rosário Vellano/UNIFENAS - Rod 179 Km 0, 37.132-440 - Alfenas - MG - ligiane.florentino@unifenas.br

Coffee Science, Lavras, v. 14, n. 2, p. 157 - 162, apr./jun. 2019 
seasonal rainfall and evapotranspiration loss according to (FAVARIN et al., 2013).

Coffee (Coffea arabica L.) originated in the African continent, Ethiopia, formerly Abyssinia (SANTOS, LIMA and CARVALHO, 2016), normally developing under tropical sub-forest conditions under the shade of native tree species of the region. In this way, it is verified that coffee is adapted to shaded environments, according to Paiva, Guimarães and Souza, (2003), which can be explained due to the fact that it has a metabolic pathway of type C3.

Baliza et al. (2014) state that in Central America the cultivation of coffee plantations in agroforestry systems is a common practice and is widely used by native coffee growers in order to maintain a microclimate more favorable to the crop and somewhat similar to the regions of the coffee tree origin.

In Brazil, coffee cultivation occurs predominantly under sun light, since the most cultivated species such as Coffea arabica and $C$. canephora have adapted in a very practical way to this management type, but the use of techniques that promote the shading of the coffee plantations has been reported and adopted by several coffee growers (MORAIS et al, 2009).

Coffee cultivation in agroforestry systems has been a sustainable production option developed by family farms, providing benefits related to better adaptation to high temperature conditions and low rainfall availability (VIEIRA et al., 2015).

The use of shading practice to coffee tree presents changes in the microclimate promoting physiological and anatomical changes in the plant according to Morais, (2003), minimizing the effects of high temperatures and water deficit, minimizing the biennial production and positively reflecting the harvests stability (RENA \& MAESTRI, 1985; VAAST et al., 2005).

This alternative is a technical option for mitigation in a possible scenario of global warming and its effects (FAZUOLI et al., 2007). Rodrigues et al. (2015), point out that shading with tree species to cover the soil can reduce the limitations imposed by climate change, aiming at better soil and plant water storage.

Pereira (2004) states that research has already shown some plant species as promising to green manure in a intercropped with coffee such as: Crotalaria (Crotalaria juncea L.), pigeon pea (Cajanus cajan L.) and black mucuna (Stilozobium aterrimum L), considering that there are a large number of family-owned also cultivate annual species in a intercropped as an income source, generally cultivated with low planting density, providing better soil use during coffee crop formation (PAULO et al., 2004)

The cultivation of coffee with forest planting is a traditional technique in several countries of the world and has been arisen countless studies as an option to minimize the effects of climate change and promote the sustainability of coffee cultivation (GUIMARÃES et al , 2015).

In Central America, this practice promotes benefits to the plant-climate-soil system, contributing to the formation of vigorous plants protected against frost and high temperatures, improving soil physical structure by increasing organic matter (MORAIS et al., 2007).

The coffee crop implantation is one of the sustainability pillars, since in the cultivation of perennial crops it is difficult to correct errors occurred in its establishment. Planting is a set of detailed actions that are fundamental to the activity success and the imperfections will reflect throughout its productive cycle generating direct impacts on its profitability (MESQUITA et al., 2016).

Therefore, due to the sustainable promotion importance of the coffee crop, the current concern with the predictions of negative climate changes to the activity development and the search for alternatives that minimize these climatic impacts, the realization of this research project aimed to evaluate the cultivation of different plants in intercropped for shading of the coffee tree and its influence on the seedlings establishment, development, coffee growth and the maintenance of lower soil temperatures.

\section{MATERIAL AND METHODS}

The experiment was carried out in the Santa Felicidade Site, located in the municipality of Campestre - South of MG, located at $21^{\circ}$ 43' 12 "South and 46 ${ }^{\circ} 14$ ' 46" West and 1106 meters and with hot and temperate climates. The summer with higher rainfall index than the winter has been classified as Cwb according to Köppen and Geiger. The average annual temperature is $18.9^{\circ} \mathrm{C}$. The average annual rainfall is $1609 \mathrm{~mm}$ according to Clima-Date.Orgwebsite. The cultivar of coffee implanted was Catuai IAC 144, seedlings with 4 pairs of leaves, planted on 12/10/2016 and intercropped with the following plants: corn (Zea 
mays L.), guandu (Cajanus cajan L.), crotalaria (Crotalaria spectabilis L.), mucuna (Stizolobium aterrimun) and control without any intercalary species, totaling 5 treatments. All the intercropped plants were cultivated within $50 \mathrm{~cm}$ of the coffee line, aiming to provide shading on the coffee seedlings.

The sowing of the shading plants was carried out 45 days before the coffee plantation on $10 / 25 / 2016$, with a manual planter popularly known as hand planter. The spacing between the lines of crotalaria, guandu and mucuna were at 20 $\mathrm{cm}$ and the corn at $50 \mathrm{~cm}$.

Planting was carried out in 4 plots per treatment, in a randomized block system - DBC with 14 coffee plants per plot, being used to evaluate the 10 central plants.

The shading plants were kept in the first year until September/2017, being sown again in December/2017 and managed until September/2018. The shading plants were kept in the first year for 9 months, being sown again in December and maintained for another 9 months.

The same cultural dealings were used for all treatments, with base fertilization using $\mathrm{P}_{2} \mathrm{O}_{5}$ source and well-tanned bovine manure, $3 \mathrm{~N}$ and $\mathrm{K}$ weed control fertilizers, with the use of preemergent herbicide Oxyfluorfen and 2 sprays with mineral salts and systemic fungicide.

After 22 months, the following characteristics were evaluated: seedlings glue (\%), plant height $(\mathrm{cm})$, average length of plagiotropic branches at $50 \mathrm{~cm}$ of soil $(\mathrm{cm})$, number of internodes in plagiotropic branches, coffee canopy area at $50 \mathrm{~cm}$ soil level $\left(\mathrm{cm}^{2}\right)$ and soil temperature $\left({ }^{\circ} \mathrm{C}\right)$, which was measured every 13:00 hours weekly, using an infrared thermometer. The data were interpreted statistically by means of variance analysis and the grouping means was carried out by the Scott Knott test at 5\% of probability using the statistical software SISVAR ${ }^{\circledR}$ (FERREIRA, 2014).

\section{RESULTS AND DISCUSSION}

After data analysis, it was verified that there was no statistical difference between the treatments for the coffee seedlings establishment parameter. Regarding the plants height, a positive effect of the treatments containing the plants establishment for shading was observed, according to the data presented in Figure 1.

The treatments that used crotalaria and guandu were the ones that presented higher height, on average $35 \%$ higher than the control treatment (without shading plants). These results corroborate studies carried out by Paiva, Guimarães and
Souza (2003), wherein researching the influence of different shading levels by shading screen on the seedlings coffee growth verified a variation coefficient at $9.03 \%$ in the various treatments applied.

The use of shading plants also influenced the average length of plagiotropic branches and the coffee canopy area, both measured at $50 \mathrm{~cm}$ from the soil, when compared to the control treatment, as can be observed in Table 1 .

Regarding the average length of plagiotropic branches, the treatment containing crotalaria at $50 \mathrm{~cm}$ from the soil there was a statistically significant difference with an increase of $42 \%$ when compared to the control treatment plot and obtaining a lower result when planting intercalary corn.

Regarding to the coffee canopy area development, the treatment with crotalaria presented increments of approximately $100 \%$ when compared to the control treatment. Pezzopane et al. (2010), conducting research between intercropped of Macadâmia tetraphylla L. and coffee concluded that this interaction between cultures promoted in the shading influences in the local microclimate, leading to a lower coffee tree exposure to the solar radiation, thereby reducing the active photosynthetic region of the coffee tree. Not finding relevance for changes in the growth and development of coffee trees, researches with different results from those found in the present study.

In Table 2 we can observe the results obtained for the shading influence on the number of internodes of the plagiotropic branches measured at $50 \mathrm{~cm}$ from the soil.

According to data presented in Table 2, it was verified that there was a positive variation in relation to the internodes growth of the plagiotropic branches, with the plants in intercropping of shading in relation to the control. It was possible to observe the treatment that presented a greater number of internodes of the plagiotropic branches to $50 \mathrm{~cm}$ of the soil was when the use of Crotalaria as plant for the shading.

The results obtained for the Crotalaria species in relation to the number of plagiotropic branches do not corroborate with the results of researches found by Morais et al. (2003) when the morphological evaluation of the coffee tree shows provided by banana plants did not contribute to the enlargement of the internodes located in the young plagiotropic branches, probably due the planting density, because shading causes changes in the microclimate may cause changes in the coffee tree anatomy. 


\section{Coffee plants height $(\mathrm{cm})$}

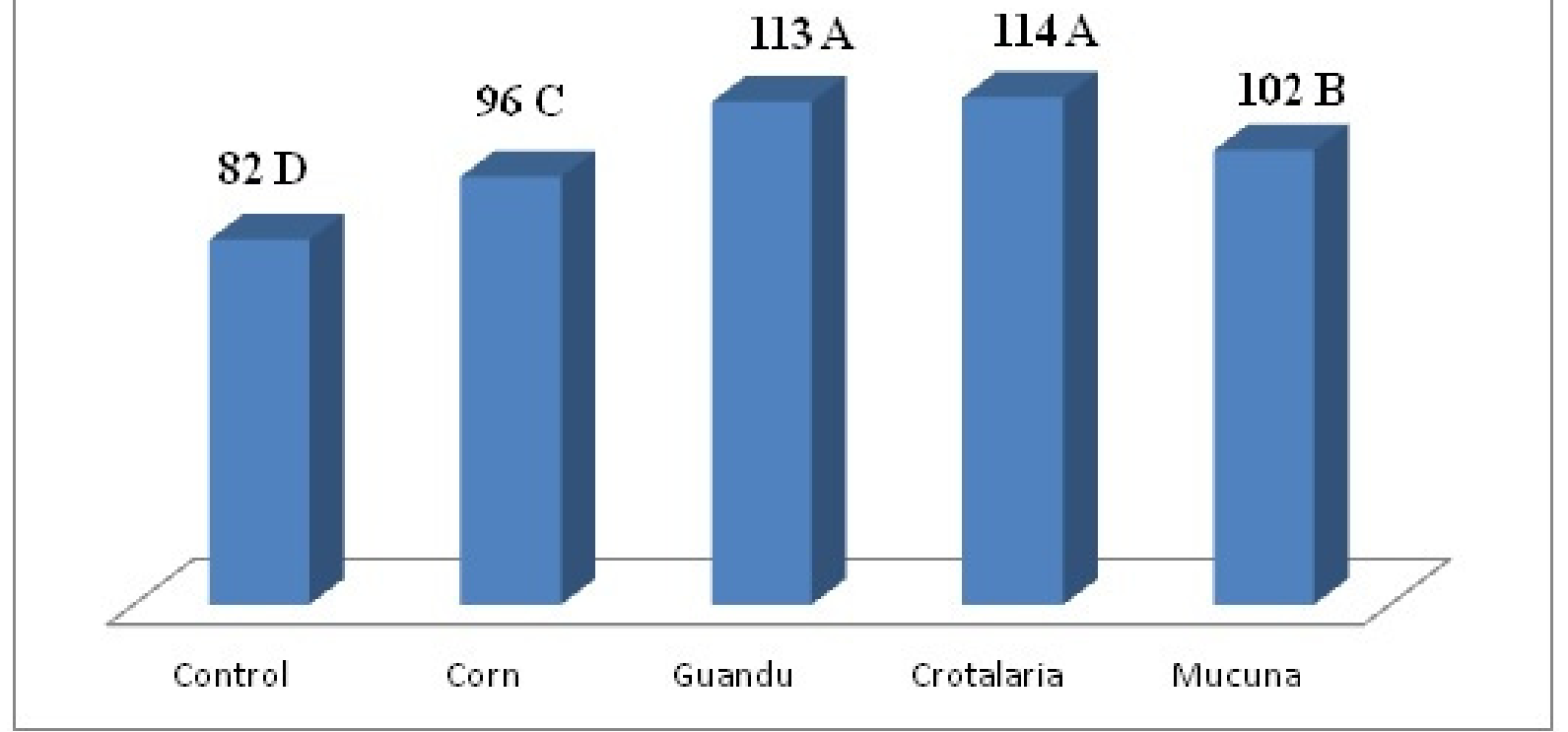

FIGURE 1 - Coffee plants height

* Numbers followed by the same letters belong to the same cluster by the Scott Knott test at $5 \%$ probability.

TABLE 1 - Average length of plagiotropic branches and crown area at $50 \mathrm{~cm}$ from the soil.

\begin{tabular}{ccc}
\hline Treatments & Plagiotropic Branches Length $(\mathrm{cm})$ & Crown area at $50{\mathrm{~cm}\left(\mathrm{~cm}^{2}\right)}^{2}$ \\
Control & $71 \mathrm{D}$ & $1.58 \mathrm{D}$ \\
Crotalaria & $102 \mathrm{~A}$ & $3.26 \mathrm{~A}$ \\
Guandu & $99 \mathrm{~B}$ & $3.07 \mathrm{~B}$ \\
Corn & $82 \mathrm{C}$ & $2.11 \mathrm{C}$ \\
Mucuna & $98 \mathrm{~B}$ & $3.01 \mathrm{~B}$ \\
\hline
\end{tabular}

*Average followed by the same letters in the column belongs to the same cluster by the Scott Knott test at $5 \%$ probability.

TABLE 2 - Number of internodes of the plagiotropic branches at $50 \mathrm{~cm}$ from the soil.

\begin{tabular}{cc}
\hline Trataments & Number of internodes of the plagiotropic branches \\
\hline Control & $12.3 \mathrm{D}$ \\
Crotalaria & $18.2 \mathrm{~A}$ \\
Guandu & $17.8 \mathrm{~A}$ \\
Corn & $15.2 \mathrm{C}$ \\
Mucuna & $16.7 \mathrm{~B}$ \\
\hline
\end{tabular}

*Averages followed by the same letters in the column belong to the same cluster by the Scott Knott test at 5\% probability. 
The same authors in 2004 also confirmed changes in plant physiology. In 2008, they stated "these impacts depend on the type, density, duration and time of shading, as well as the current climatic conditions and local climate, tested genotype, plant age, among other factors" (MORAIS et al., 2008). For positive results achieved in the present research, it is possible to verify the relation existing as a size function of the cultivated plants between the streets of the crop in formation.

Table 3 presents the results obtained for the characteristic average temperature of the soil when using shading for growing coffee trees.

According to the results shown in Table 3 the important contribution that is the use of cover crops in a intercropping with the coffee tree in relation to the maintenance of a mild temperature in the soil is observed. According to Ragassi et al (2013), soil temperature at $33^{\circ} \mathrm{C}$ promotes the death of part of the roots that absorb water and nutrients. He also mentions that "the radicels meristem are responsible for the hormones synthesis that control both the coffee tree and the stomata regulatory system development that does not allow the excessive loss of water in the breathing process".

Therefore, this work demonstrated that even in the treatment with Mucuna that presented the higher soil temperature when compared to the other treatments did not allow the soil temperature reach the temperature $33{ }^{\circ} \mathrm{C}$; while the control treatment reached $42.3{ }^{\circ} \mathrm{C}$ which probably damage the root system development, thus negatively reflecting the development of coffee trees in formation.

\section{CONCLUSIONS}

It was concluded that the use of shading plants in a intercropping with the coffee tree managed in the post-planting and first-year phases contributed to a better coffee development, observed mainly in the treatments with Crotalaria and Guandu.

\section{ACKNOWLWDGEMENT}

The authors are grateful to the José do Rosário Vellano University (UNIFENAS), the CAPES, the CESEP Higher Education and Research Center, CESEP's Coffee Research Center, the Minas Gerais State Technical Assistance and Extension Company - EMATER - MG, the owner of Sitio Santa Felicidade and Seeds Pirai, that contributed much to the development of this research.

\section{REFERENCES}

BALIZA, D. P.; SANTOS, M. O.; ALVES, J. D.; GUIMARÃES, R. J.; CUNHA, R. LUZ. Metabolismo da sacarose em cafeeiros submetidos a diferentes níveis de sombreamento. Lavras, Coffee Science, v. 9, n. 4, p. 445 - 455, out. /dez. 2014.

FAVARIN, J L, et al, Novo conceito no preparo do solo para a lavoura cafeeira, Visão agrícola ${ }^{\circ} 12$ JAN | JUL 2013, p.20-22

FAZUOLI, L.C. et al. Aquecimento global, mudanças climáticas e a cafeicultura paulista. O Agronômico, v.59, n.1, p.19-20, 2007.

FERREIRA, D. F. Sisvar: um guia dos seus procedimentos de comparações múltiplas Bootstrap. Ciência e Agrotecnologia, v. 38, n. 2. p. 109-112, 2014.

GUIMARÃES, N.F. et al. Influência de sistemas de produção de café orgânico arborizado sobre a diversidade da fauna invertebrada epigéica. Coffee Science, vol. 10, n. 3, 2015. p. 280-288.

MESQUITA, C. M.; et al. Manual do café: implantação de cafezais Coffea arábica L. Belo Horizonte: EMATER-MG, 2016. 50 p. il.

MIRANDA M. Questões Climáticas e a Cafeicultura Brasileira. Cecafe - Conselho dos exportadores de café, 2016. Disponível em: www.cecafe.com.br/ sem-categoria/questoes-climaticas-e-a-cafeiculturabrasileira-20161207/. Acesso em 08 jan. 2019.

TABLE 3 - Average soil temperature ${ }^{\circ} \mathrm{C}$.

\begin{tabular}{cc}
\hline Trataments & Soil temperature ${ }^{\circ} \mathrm{C}$ \\
\hline Control & $42.3 \mathrm{D}$ \\
Crotalaria & $24.9 \mathrm{~A}$ \\
Guandu & $25.3 \mathrm{~A}$ \\
Corn & $29.4 \mathrm{~B}$ \\
Mucuna & $32.2 \mathrm{C}$ \\
\hline * Averages followed by the same letters belong to the same cluster by the Scott Knott test at 5\% probability.
\end{tabular}


MORAIS, H. et al. Características fisiológicas e de crescimento de cafeeiro sombreado com guandu e cultivado a pleno sol. Pesquisa Agropecuária Brasileira, Brasília, v. 38, n. 11, p. 1131-1137, nov. 2003.

Modifications on leaf anatomy of Coffea arabica caused by shade of pigeonpea (Cajanus cajan). Brazilian Archives of Biology and Technology, Curitiba, v. 4, n. 6, p. 863-871, 2004.

Desenvolvimento de gemas florais, florada, fotossíntese e produtividade de cafeeiros em condições de sombreamento. Pesquisa Agropecuária Brasileira, Brasília, v. 43, n. 4, p. 465-472, abr. 2008.

MORAIS, H, et al. Sombreamento de cafeeiros durante o desenvolvimento das gemas florais e seus efeitos sobre a frutificação e produção, Ciência Rural, Santa Maria, v.39, n.2, p.400-406, mar/abr, 2009

MORAIS, H.; CARAMORI, P.H.; KOGUISHI, M.S.; ANDRADE, G.A. E SOUZA, F.S.D. (2007) - Microclima de café cultivar Iapar 59 consorciado com guandu (Cajanus cajan) no norte do Paraná. In: SIMPÓSIO DE PESQUISAS DOS CAFÉS DO BRASIL, 5. Anais do simpósio de pesquisa dos cafés do Brasil. Brasília, Distrito Federal, p. 1-4.

MORAIS, H. Efeito do sombreamento de cafeeiros (Coffea arabica L.) com guandu (Cajanus cajan (L) Millsp.) no Norte do Paraná. 2003. 118f. Dissertação (Mestrado em Agronomia) - Universidade Estadual de Londrina, Londrina, PR.

PAIVA, L. C.; GUIMARAES, R. J.; SOUZA, C. A. S. Influência de diferentes níveis de sombreamento sobre o crescimento de mudas de cafeeiro (Coffea arabica L.), Ciências e Agrotecnologia, Lavras. V.27, n.1, p.134-140, jan. /Fev 2003

PAULO, M. E. et al. Comportamento do cafeeiro apoatã em consórcio com culturas anuais. Bragantia, Campinas, v.63, n.2, p.275-281, 2004.
PENEREIRO, J.C. \& MESCHIATTI, M.C; Tendências em séries anuais de precipitação e temperaturas no Brasil, Eng Sanit Ambient,v.23, n.2 , mar/abr 2018, p. $319-331$

PEREIRA, A. J. Produção de biomassa aérea e de sementes de Crotalaria juncea a partir de diferentes arranjos populacionais e épocas do ano. (2004) Dissertação (Mestrado) - Seropédica, RJ, Universidade Federal Rural do Rio de Janeiro, 68p

PEZZOPANE, J. R. M., et al. Condições microclimáticas em cultivo de café conilon a pleno sol e arborizado com nogueira macadâmia. Ciência Rural, Santa Maria, v. 40, n. 6, p. 1257-1263, 2010.

RAGASSI, C. F.; PEDROSA A. W.; FAVARIN, J. L. Aspectos positivos e riscos no consórcio cafeeiro e braquiária. Visão Agrícola, Piracicaba, n.12, p. 29-32, jun./jul. 2013.

RODRIGUES, W. P.; et al. Long-term elevated air $\left[\mathrm{CO}_{2}\right]$ strengthens photosynthetic functioning and mitigates the impact of supra-optimal temperatures in tropical Coffea arabica and C. canephora species. Global Change Biology. v.22, p.415- 431, 2015.

SANTOS, N. A dos, LIMA, T. dos, CARVALHO, V. C. $\mathrm{H}$ dos, Efeitos fisiológicos do Coffea arabica para o organismo humano: evidências e controvérsias, Revista Diálogos \& Ciências. Ano 16 No 36 Junho 2016, p.130.

VAAST, P. et al. Fruit thinning and shade improve bean characteristics and beverage quality of coffee (Coffea arabica L.) under optimal conditions. Journal of the Science of Food and Agriculture, v.86, p.197-204, 2006.

VIEIRA M V M, et al, Indicadores de sustentabilidade e influência de sistemas agroflorestal e convencional sobre a qualidade do solo e do café arábica em PiumhiMG, Revista Verde (Pombal - PB - Brasil) v. 10, n.2, p. 229 - 238, abr-jun, 2015 